\title{
The Culture of Resilience: Providing Solutions for Urban Space Vulnerability to Recurrent Unfavourable Climatic Phenomena
}

\author{
Valderez Ferreira Fraga ${ }^{1}$ and Ana Paula Gomes M. Pinto ${ }^{2}$ \\ 1. Institute of Economic (Ecex), Federal University of Rio de Janeiro, Rio de Janeiro, CEP 22.290-902, RJ, Brazil; \\ 2. Department of Production and Civil Engineering, University Unilasalle, Niteroi, CEP 24240-030, RJ, Brazil
}

\begin{abstract}
Urban spaces vulnerable to recurrent adverse climatic phenomena present specific, consecutive problems, requiring a reflective view of their socio-spatial reality. This article presents a case study about the towns of Amadora, Greater Lisbon, and Petrópolis, Rio de Janeiro State, Brazil, which, originally, bore a common Portuguese urbanistic praxis. Their urban contexts are characterized by the occurrence of extreme risks of flooding and landslides caused by intense rainfall. Both places feature aggravation of the risks due to accelerated urban growth and disorderly land occupation. From the phenomenological perspective, what happens to the human being leads to fruitful and/or dramatic experiences. The important point is that there occurs learning for favourable action, with solutions for each individual and for "the other". Thus, it is proposed to qualitatively analyse, with a posture that values the community experience and urban practices of the towns that contribute to the development of the culture of resilience which promotes practices of prevention, precaution and vigilance founded on the experience of communities that have been exposed. Besides this, it is intended to verify challenges in the implementation of public policies aimed at sustainable urban development, those that contemplate, among others: risk management action to deal with natural disasters.
\end{abstract}

Key words: Urban spaces, culture of resilience, phenomenology, community, natural catastrophe/disaster.

\section{Introduction}

The city of Petrópolis, situated in the Serrana region of Rio de Janeiro State, Brazil, is no exception to the rule when it comes to the population growth observed in most cities, and mainly in Brazil, where the urbanization rate today has reached around $80 \%$. The phenomenon of urban growth is set against an absence of improvements in infrastructure that is detrimental to the quality of life of the citizens. Moreover, this has not even been the object of public policies aimed at avoiding the negative impacts on natural resources. On the contrary, these are becoming

Corresponding author: Valderez Ferreira Fraga, associate professor; research fields: organizational and educational management, culture, phenomenological philosophy, ethics and climate issues. E-mail: valorerh@centroin.com.br.

Ana Paula Gomes M. Pinto, assistant professor; research fields: culture of resilience and climate change in the urban environment. E-mail: ap_gomes1@hotmail.com. scarce due to the disorderly nature of the urban expansion on the periphery [1].

This phenomenon is also present in the city of Amadora, situated in the large metropolitan area of Lisbon. It is the fourth most populated city in Portugal. In the $60 \mathrm{~s}$, Amadora changed from being an industrial and residential suburb to a suburban city. As a consequence, the population flow and its concentration in the territory of Amadora - as well as in the surrounding area-have led to high pressure on urban space, the public services, and, of course, the organizations and institutions in charge of administering them. This condition configures a crisis of urban growth [2].

Although the cities present specificities in their formation and urban layout, the cultures coexist and feel the same socio-environmental impacts attributed to urban densification, aggravated by climate change, 
which, as a consequence, generate natural catastrophes. In their search for solutions and alternatives, we have adhered to the UN (United Nations) international campaign, Constructing Resilient Cities 2010-2015, which addresses issues of local governance and proposes development of assets of good practices that would make all communities more resilient after facing disaster situations.

Both seek to articulate the managerial instruments of prevention with the urban planning, as well as the information programmes, mobilization and awareness with the aim of reducing disaster risk.

Thus, the objective of this study is to verify possible solutions to minimize the impacts of urban flooding and reflect on the importance of the strengthening of the culture of resilience in the alternative practices of local communities, as well as considering assumption of a philosophical posture towards the common wellbeing of the world community while acting locally.

At this point, it was considered basic to include a presentation of a Gabriel Marcel's (195-), the Christian Existentialist [3], as well as expression [4] to describe the relationship subject-world density - "être-au-monde" — which clarifies the inextricable: the man insertion in the world and the world presence on man. In this sense, the phenomenological posture demands that relationship also is to be assumed "as a life-style" [5] what is obviously fundamental for the concretization of the proposition presented above.

\section{Methodology}

In opting for the case of Amadora as a reference to an analysis of the Brazilian reality, it is prudent and could be productive, due to the cultural proximity to Brazil's cultural origin and the logic of Portuguese language, as, albeit situated on the European continent, Portugal inevitably left undeniable cultural traits [6].

Upon embarking on this study, a query on the part of Dartigues emerged as an alert regarding its development. He asked: "would it be possible to conceive of dignified humanity without philosophers?" [7]. For the second time, this provocation, stimulating in its reflections about the environmental theme, motivated a second question, one regarding management: would it be sufficient to have a theoretical base for management practice from which philosophical fundamentals were lacking?

In view of the theme's orientation towards the social, fundamental philosophic-phenomenological elements at the base of this discussion were considered to be a necessity. This is because phenomenology, despite making clear its own conception of method-not a path to be followed a priori, but that of the things themselves, in an insertion into the movement of that which happens, distinguishes the traditional justification of the action from its legitimation in the world of the living, implying imbrication between fact and value [5]. Besides this, "The possibility of dialogue between the philosophy of experience and phenomenology is important..., because it makes the criterion of relevance appear, which reveals the philosophical meaning of the administrative action. This, as well as being intentional, conscious and essential to the human mind, becomes more comprehensive than mere justification of the results, seeking legitimation only after consideration of the implications of its application to practice, in the real world" [5].

Therefore, this legitimate self-assertion in the face of the action coexisting authentically in common in resilience, reveals the synthesis aspired by phenomenology and the philosophy of experience: result and consequence taken as universally indissociable in the discourse and practice in the action. This recognizably ambitious proposal, given the fragility of the ethical posture in day-to-day human life, is the aspiration of this study/proposal. 


\section{From the Urban Specificities to the General Notion}

There are innumerable factors that interfere with the result of construction in city space, such as the configuration of the site, the different interests on the part of the agents and actors, along with the local culture, which directly interfere with the appropriation of the place.

In 1846, the German engineer, Júlio Frederico Koeler presented the project for the Vila Imperial de Petrópolis, which was in a tentacular form, accompanying the courses of the rivers and streams, and divided into a dozen blocks around the centre (see Fig. 1).

Observing the project and associating it to the decree in the period, an urbanistic plan was contemplated, with clear indications of zoning, roadway hierarchization, occupation and construction norms, differentiated land division, environmental protection, water supply and sewage disposal. Among the actions of Barão de Mauá, the introduction of railways marked an emblematic historical period. The first railway in Brazil, inaugurated in 1854, linked the port, Estrela on Guanabara Bay to the foot of the Serra de
Petrópolis mountain range [8]. Furthermore, considering the topography of the place with its geological and geotechnical peculiarities, the characteristics of the Mata Atlântica forest, and the course, volume, etc. of the rivers involved, we conclude that the plan was perfectly adequate for the natural conditions of the site, and, therefore, devised founded on scientific premises [8].

Regarding the design and use of the centre, the relation between the roadway system with the Serra da Estrela highway, the categories, dimensions and destinations of the periods, indicate there was intentionality in the urban design. The origin of the city of Petrópolis featured a path that did not follow the general urbanistic pattern, resembling a chessboard, not even the colonial Portuguese pattern with an irregular path, with rivers in the background of the plots of land. Originally, it was destined to be a work of imperial determination, a scientific idealization of European construction [8].

With the accelerated urbanization process as of the $70 \mathrm{~s}$, the disobedience of the environmental protection and preservation laws have increased the magnitude of the impacts to extreme levels (Fig. 2). The population

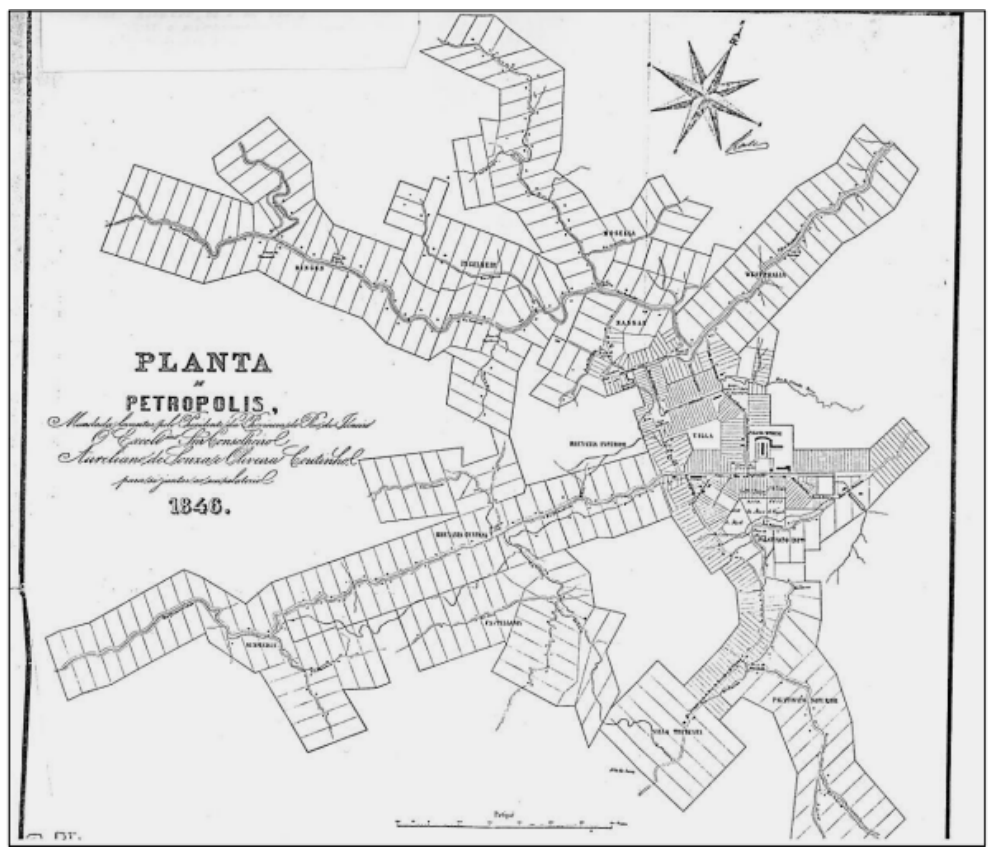

Fig. 1 Plant of Petrópolis (1846). 


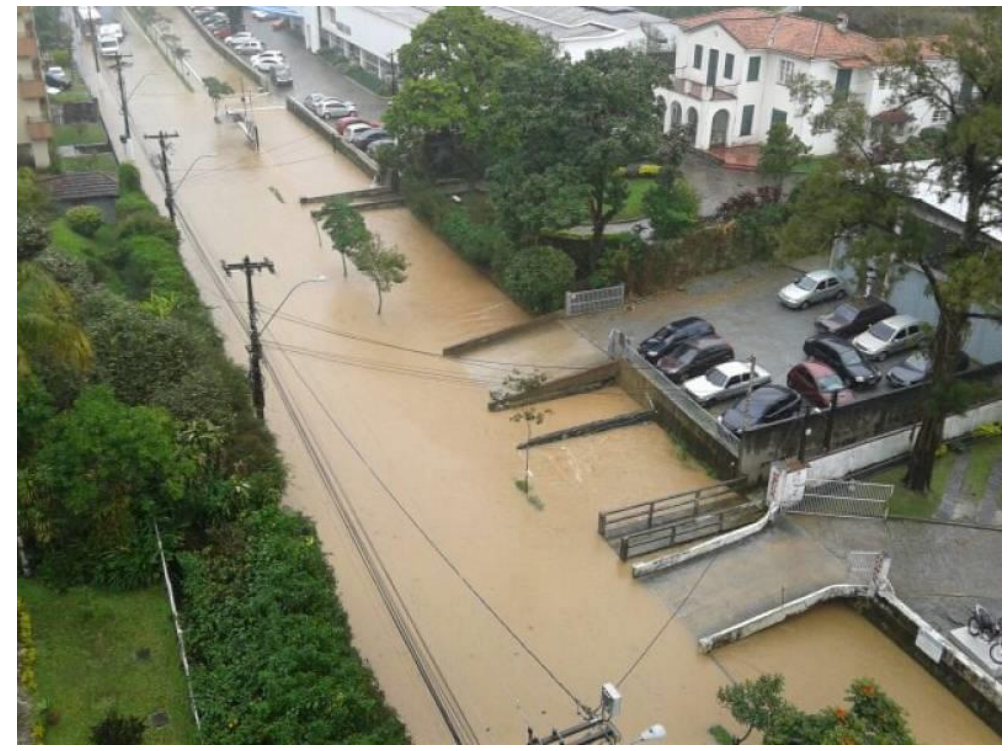

Fig. 2 In Petropolis, the streets were built on the banks of the rivers, which favor floods [9].

increase has led to a greater quantity of sewage dumped into water bodies. As the land adjacent to the rivers had already been occupied, concentration of population in the central area of the city and valley bottoms has led to a great occupation of the surrounding region, driven by property speculation that has neglected the non-occupation distances established by law [1].

The municipality of Amadora (1960-1974), situated in Lisbon's first expansion zone, had the following principal urban growth inducing elements:

"The railway line, the roadway network (in particular the royal highways and, later, the regional network), plus the creation of a vast area adjacent to Lisbon where large manufacturing industries have been established (Venda Nova). Thus, the proximity and easy access to Lisbon, along with the exit of residents from the capital due to the expansion of tertiary activities, are factors that explain the growth in demand for housing and installation of economic activities in Amadora" (Fig. 3) [10].

In this way, Amadora rapidly constituted Lisbon's most important suburb - notably becoming the fifth largest housing nucleus in the country [11] in 1960. The case of Amadora is significant in terms of how suburbanization constituted the most important process of population redistribution in the Lisbon agglomeration in the 50s, 60s and 70s [2] —akin to the main European cities [12].

The specificity of the Lisbon Metropolitan Area overlapped, among others, phenomena like the suburbanization and peri-urbanization; the successive diversified flows of immigrants; the urbannobilitation and rehabilitation of the historic districts [13]; the deindustrialization and industrial relocation; the deconcentration of economic activities and coastal urbanization linked to tourism and leisure by means of notable improvements in accessibility [10].

Among the elements considered in the physical formation of these cities, one may notice that the natural geographical characteristics are not addressed in a consistent manner, and the site becomes the preponderant articulating component between nature and the city. Some scholars of urban form perceive the site as a product of articulation of the parts that form the natural environment, such as water courses, lakes, oceans, relief and vegetation, but each of these parts is not studied separately. Besides this, both evolve differences of hierarchy and status, and the latter are established as constitutive of the different meanings attributed to the suburban experience.

The site is perceived as the primordial element in the 


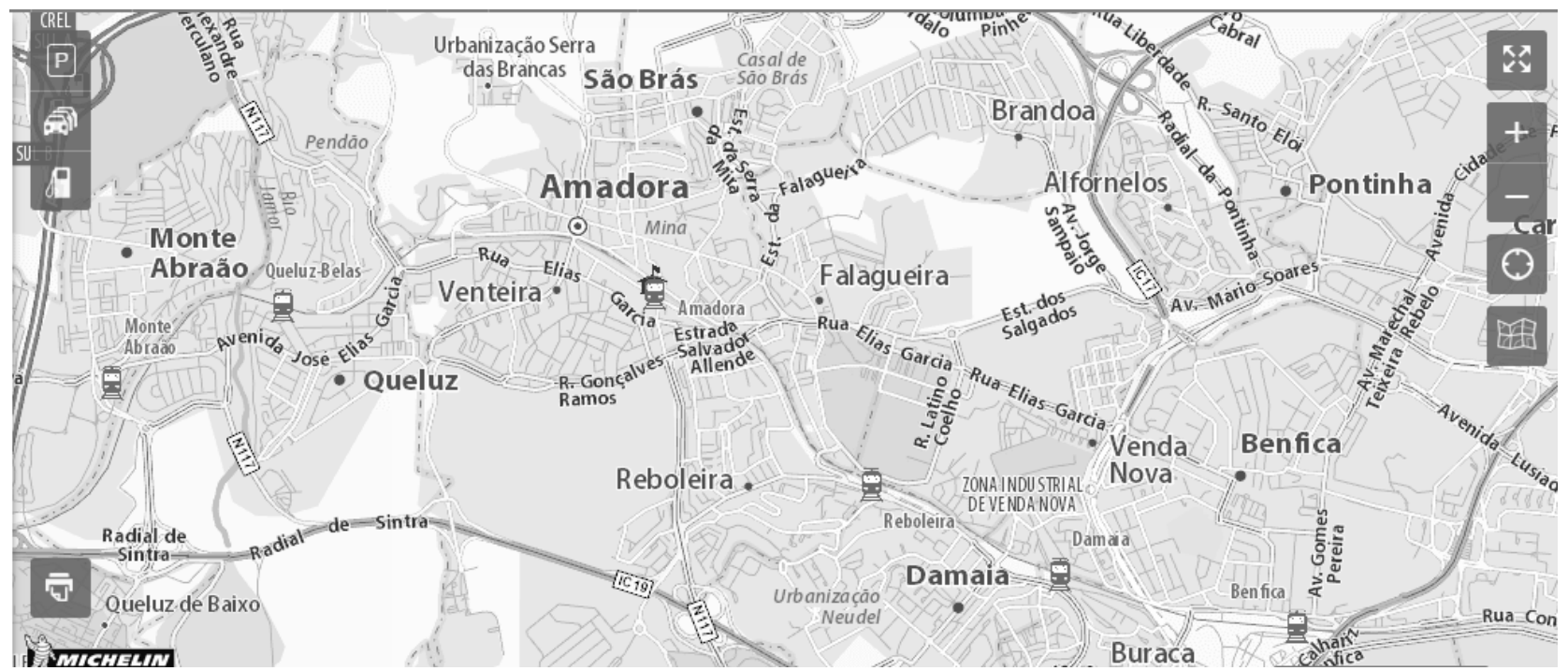

Fig. 3 Map of Amadora, area adjacent to Lisbon.

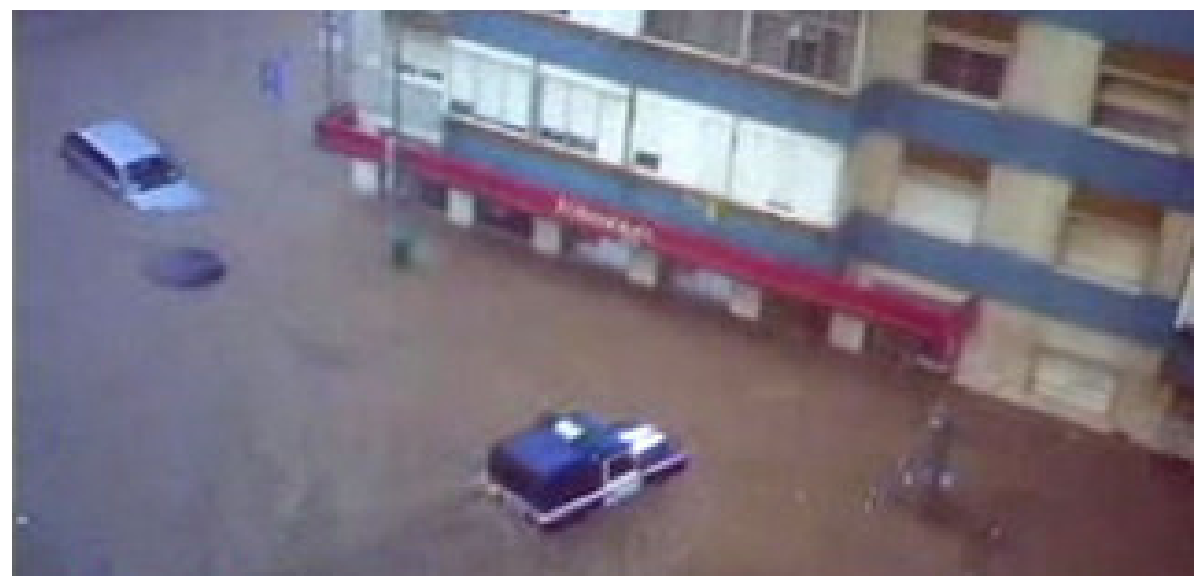

Fig. 4 In Damaia, in the Council of Amadora, traffic on inundated street was interrupted [14].

spatial configuration of the urban form. The elements that comprise the space, such as roadways, plots of land, buildings and the possible arrangements among them, give rise to other elements, such as blocks and their layout, which comprise various models and give rise to cities (Fig. 4). Moreover, it is possible to identify the ways in which they will be vulnerable, and also develop solutions to minimize the impacts of natural catastrophes.

In parallel, one must also observe that cities present other systems of meanings, other spheres and nuances of social practices. Drawing from philosophical thought [15], the discourse of the city has its particular language games that differ in their logic and reach from those manifested at the linguistic level, and within this, in their distinct thematic plans. On the other hand, Victor Hugo homologated the city as a book [16].

For Barthes [17], "the city is a discourse, and this is truly a language: the city speaks to its inhabitants". The city does not only function, but also communicates. Based on this presupposition, the cities are an immense laboratory of trial and error, success and failure, in terms of construction and urban design. It is in this laboratory that the urban planning should learn, devise and test its theories [18]. Therefore, more than knowing how to plan, it is important to know how to interpret the lexical polysemy of the city, which houses the old and the contemporary, whose existence is complex and dense. 


\section{The Urban Drainage Plan: Problem and Solutions}

A significant part of the impacts caused by natural catastrophes are accentuated in urban areas that present an accelerated, disorderly urbanization process, without planning and implementation of actions that are conducive to adequate land occupation. In the absence of norms that regulate such occupation, it is inevitable that large areas become impermeable, due to buildings, pavements, paved streets, and the urban densification itself.

Compensatory drainage measures, such as: infiltration trenches, permeable paving, and micro reservoirs for runoff containment, have proven to be good control instruments for surface drainage. Their use has become possible through urban drainage planning that has begun to oblige new constructions to adopt alternative means of urban flood control [19].

In an attempt to minimize the effects of flooding caused by heavy rain, the cities of Petrópolis and Amadora have identified a need to implement urban drainage plans, as set out below.

Since the natural catastrophes suffered in 2011 and 2013, the city of Petrópolis still awaits release of the Federal and State funds to carry out the works that are required, including those to minimize the impact of heavy rains like those suffered in January this year.

As rightly pointed out by the Mayor, Rubens Bomtempo, "rainfall on this scale is not just a problem for the municipality, but for the whole National Civil Defence System. It is necessary for everyone to play a part, but this is not happening. Throughout 2015, for example, we requested INEA (Instituto Estadual do Ambiente) [State Environment Institute in English] to dredge our city's rivers, but nothing has been done till today" [20].

In 2013, the Ministério Público [Public Ministry] filed a Public Civil Action so that Petrópolis City Hall, the Rio de Janeiro State Government and INEA would execute works to prevent the Quitandinha and Piabanha rivers from overflowing, contemplating an engineering project and reforestation of the respective riverbanks. Besides this, it requested proposals to solve the problem of unstable mountainsides in the municipality, such as slope containment works and removal of residents from risk areas [21].

The difficulty in abiding by rules, norms and procedures that are not necessarily adequate for the cultural peculiarities, or, as in the case of the Brazilian public administration, considering that the public environment possibly contains traces of patrimonialism, and does not possess adequate material conditions to execute the scheduled tasks, opens up a path for formalism to arise" [6], that is, a certain type of diversion for the purpose of pretending to do.

It is important to mention that there is occupation of a great part of the Quitandinha river basin, the result of the growth experienced in the city over the last few decades. "This expansion has contributed to the aggravation of the drainage conditions in the basin, such as increasing ground impermeability that leads to greater potential for water courses to overflow. These events have become progressively more frequent" [22].

Finally, in accordance with the Municipal Basic Sanitation Plan for the city in question, improvements are necessary in the infrastructure and operational installations of drinking water, sewage, urban cleaning and handling of solid residues, as well as drainage and handling of urban rainwater.

In 2008, the Lisbon City Hall approved a drainage plan that would provide for, among other infrastructure, the construction of a tunnel between Martim Moniz and Santa Apolónia to divert excess river flows that had frequently caused inundation of the squares, Praça da Figueira and Terreiro do Paço [23].

After approval, "the development of the plan was concluded, in effect constituting a 20-year planning instrument for the city's drainage network", covering an area of 10,282 hectares, which, according to the 
proposal, included the municipality of Lisbon and parts of the Amadora, Oeiras, Odivelas and Loures municipalities. The project would also involve flood control in the Alcântara basin, construction of a reservoir between Benfica and Campolide, and another in Avenidas Novas [23].

Besides this, the Oeiras and Amadora municipal chambers, respectively, by means of Proposta de Deliberação [Proposed Deliberation] no. 109-CMO, and no. 73-CMA, both dated February 24th, 2016, unanimously decided to ratify the decision of the Conselho de Administração dos Serviços Intermunicipalizados de Água e Saneamento [Administrative Board of the Intermunicipal Water and Sanitation] of the Oeiras and Amadora municipalities, thus commencing the procedure to create a project (Projeto de Regulamento de Drenagem de Águas Residuais dos Serviços Intermunicipalizados de Água e Saneamento dos Municípios de Oeiras e Amadora) to regulate the drainage of residual waters [24].

Based on the above, it is possible to verify that the application of urban drainage may be as much by means of structural measures as by non-structural ones, taking into account the premise that intervention must begin in the upper reaches of rivers, thereby increasing the effectiveness of the drainage and reducing the possibility of floods in other places downstream.

For the sake of clarification, the non-structural actions seek to discipline territorial occupation, people's consumer behaviour and economic activities. Considering those most adopted, the non-structural measures can be grouped as follows: actions to regulate land use and occupation; environmental education aimed at control of diffuse pollution, erosion and waste; flood insurance; flood forecast and warning systems [25].

By means of delimitation of areas subject to flooding along with risk assessment, it is possible to establish zoning and respective regulation regarding construction, and also eventual individual protection works (such as installation of panel barriers, watertight doors, and others) to be included in existing constructions.

The viability of the adjustments by means of hydraulic and soil use modeling is a way of mitigating the impact of the urbanization process, at the same time that an attempt is made to, for example, restore the natural hydrological conditions of the rivers. It also requires use of the peak rainfall, not only its diversion. Therefore, in places where such systems are applied, planning must be integrated with the urban growth, that is, with the urban landscape [26, 27]. Sustainable urban drainage presupposes integration of water in the urban environment, and its synchronization with the hydrological cycle, taking into consideration the ecological, environmental and landscape aspects along with leisure opportunities.

Such works may not put an end to flooding, but will probably reduce their frequency and minimize their effects. In this sense, it is always valid to seek alternatives for cities and their inhabitants to better resist natural catastrophes and be more resilient.

\section{The Culture of Resilience and Its Participative Practices}

Lefebvre [28] rightly observed, "only groups, classes or fractions of social classes capable of revolutionary initiatives can undertake, and fully carry out, solutions to urban problems; with these social and political forces, city renewal becomes the work".

The relevance of the human in the results of experience is the meaning sought by philosophical positions, implying engaged self-determination and profound discussions about the issue of the other end of the social. The relevance is justly the criterion whose level in administrative action, in being more comprehensive, considers the consequences of this action for the human [5]. This is irrespective of the formal governmental administration or initiatives taken by private organizations, or even of isolated action 
performed by small neighborhood groups, since the human being will always be involved.

In Petrópolis, there is an organization called NUDECS (Núcleos Comunitários de Defesa Civil) [Community Civil Defence Nuclei], formed of residents trained by the City Hall to act as volunteers in the prevention of natural catastrophes.

Since 2013, 500 have been trained for the 54 nuclei established. Furthermore, a Comitê de Ações Emergenciais [Emergency Action Committee] has been created, its purpose being to debate what is being done to render Petrópolis safer with regard to the heavy summer rains. Another mobilization initiative of the local community is Projeto Fortalecendo a Resiliência aos Desastres [Strengthening Resilience to Disasters Project], committees for school safety of formed in schools with the aim of presenting the basic concepts of what constitutes risk [29].

Faced with delay in the drainage works for the Quitandinha and Piabanha rivers, Petrópolis shopkeepers have developed a culture of resilience in order to prevent floodwater invading their stores. It is observed that increased awareness of risk leads to investment in protection to safeguard against loss due to the rains.

To illustrate the above, we highlight the initiative of two local shop owners. One had always had his shop, situated in Rua Tereza, invaded by water whenever the Quitandinha river overflowed. He used to attach quite a low panel barrier, but, after the 2006 flood event, he decided to increase the height to $1.20 \mathrm{~m}$ (see Fig. 5).

After 30 years, having suffered six floods, in each incurring a loss estimated at $\mathrm{R} \$ 50$ thousand, another storekeeper built a containment wall almost $2 \mathrm{~m}$ in height, an investment worth over R\$ 10 thousand $^{1}$ (see Fig. 6).

Based on experience and increased risk awareness, as a response to minimize the problem, shopkeepers

\footnotetext{
${ }^{1}$ Exchange rate 31/05/2017: US\$ $1=\mathrm{R} \$ 3.2357 \mathrm{BRL}$, Euro
} $1=\mathrm{R} \$ 3.6269 \mathrm{BRL}$. and community representatives, in the face of the fragility of public policies, have taken upon themselves the responsibility and the decision-making power, thereby strengthening their culture of resilience.

In 2017, the Petrópolis City Hall approved Projeto Calçada Limpa [Clean Pavement Project], which stimulated the local commerce to place refuse collection bins in front of their premises, including separation of organic waste and recyclables. So as to ensure participation of these businessmen, an information campaign was also conducted [30].

The local councillor, who presented the bill of law for this project, stresses the following benefits: "As we live in a city with rugged terrain that is detrimental to us, we need to be very careful about our rubbish. So this project will aid conservation of the environment and promote public health, given that it will avoid disease outbreaks, avoid obstruction of street drains that relieve runoff and flooding" [31]. This responsibility is also attributed to the shopkeepers and other members of the local community. It is worth remembering that these are alternative practices to mitigate the effects of heavy rain, but it is vital that there be greater mobilization and partnership on the part of the public authorities.

Based on the Campanha Construindo Cidades Resilientes [Constructing Resilient Cities Campaign], the city of Amadora, wishing to place emphasis on the local level, launched the so-called Local Campaign, "Sempre em Movimento, Amadora é Resiliente" [always on the move, Amadora is resilient] to run from 2010 to 2015. The Local Campaign team mobilised the diverse stakeholders (municipal services), local agents, civil society groups, universities and specialised organisations, offering them partnerships and local alliances. Several workshops and public sessions were organised to explain the benefits and the commitments necessary to guarantee a more resilient community. This campaign accumulated over 30 stakeholders, and there was intense mobilisation [32]. 


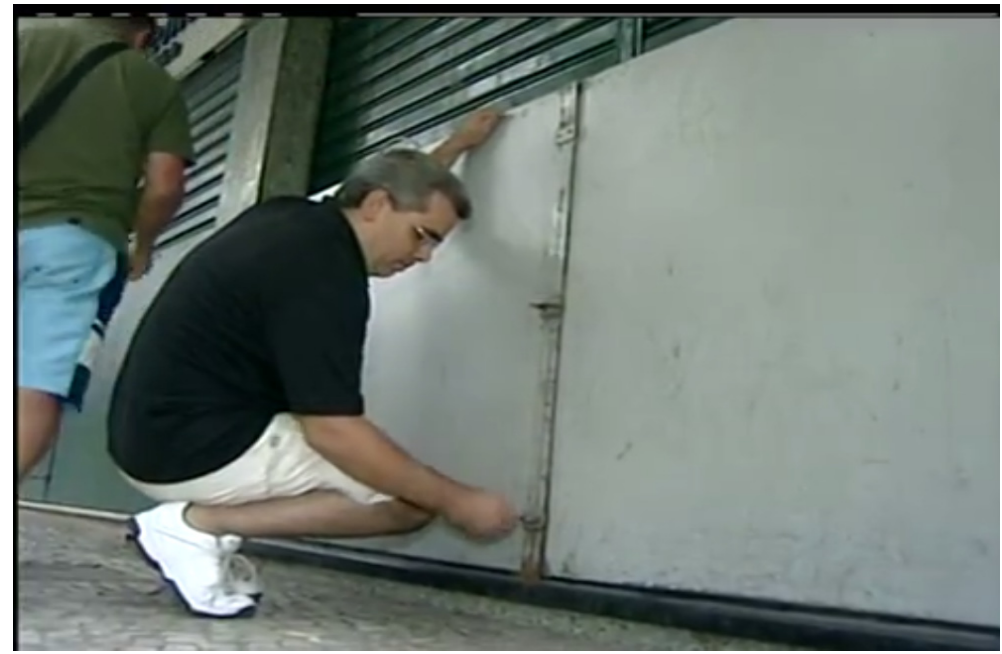

Fig. 5 Ever higher flood levels demand ever higher barriers [31].

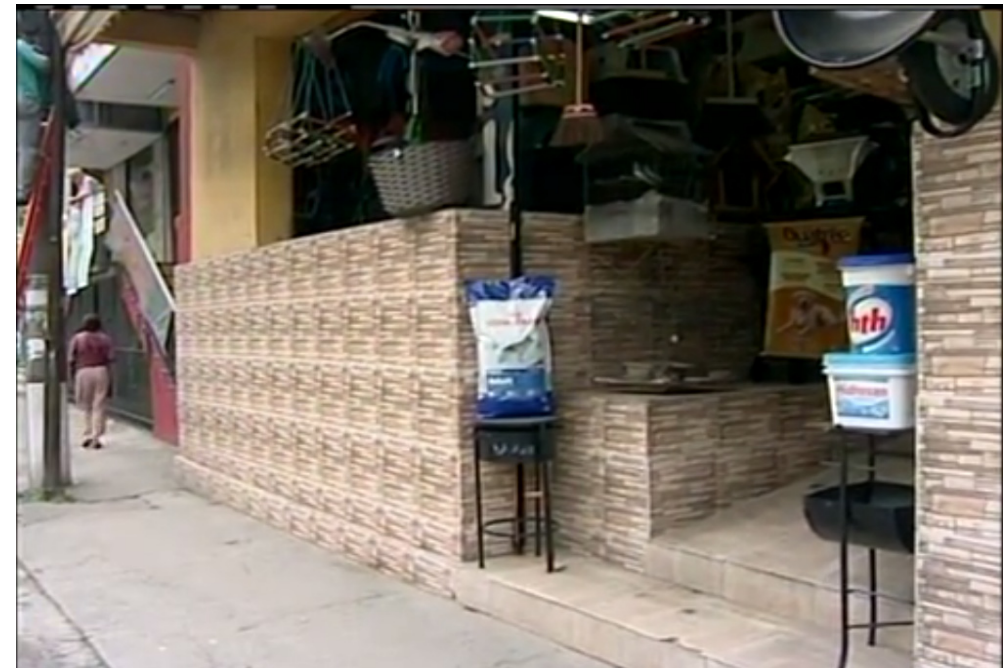

Fig. 6 Shop front flood barrier wall $2 \mathrm{~m}$ high [31].

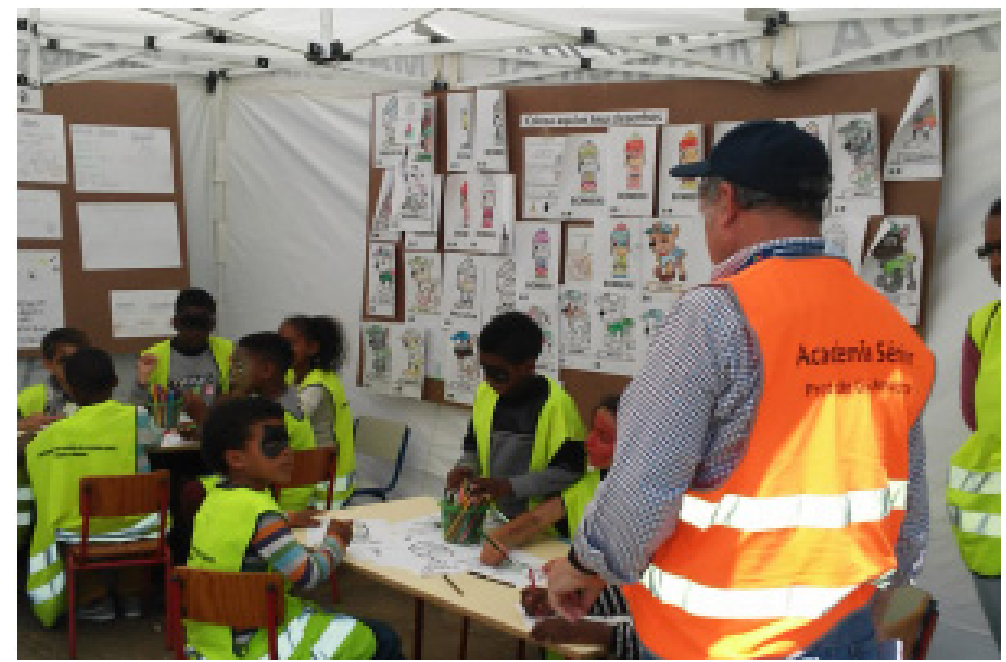

Fig. 7 Amadora Educa 2016. 
Social networks have been remarkable in strengthening the culture of resilience: Amadora Resiliente (Facebook) provides information ranging from how to proceed in case of heavy rain to techno-operational communications from the Instituto de Meterologia YouTube [YouTube Meteorological Institute] on how to reduce disaster risk on the municipal scale; Canal Amadora Resiliente (YouTube channel) is the audio-visual space of the Making Cities Resilient Campaign-Amadora and the Projeto Amadora Educa [Amadora Educational Project] (see Fig. 7).

As previously mentioned, the relevance of the human in the results of experience is the meaning sought by philosophical positions, implying engaged self-determination and profound discussions about the issue of the other end of the social. The key to relevance, according to the posture that aggregates the phenomenological essence to the philosophical experience [33], is the consideration of the consequences of the action as inseparable from the result, at any level or in any situation.

It is perceived, therefore, that the resilient city, in the domain of natural catastrophes, has a greater capacity for preparation, adaptation, anticipation, learning and self-organization due to external shocks [34].

\section{Considerations}

Reflecting [7], perceiving that "the relationship of each person with the world is as singular as each person", clarifies that there is mutual enrichment among the multiplicities of singularities in the ordinary world. It makes one see that the posture of the agent in the administrative action may strengthen authentic sharing towards participative administration, broadening its possibilities, not only based on universal abstract principles, but also on resumption of co-humanity with "mutual respect" through "co-responsibility", concretely among neighbours and public and private administrators in the cities.
They may be considered alternative multipliers of the good practices implemented, as of the moment that these communication channels and interaction can amplify the number of citizens with knowledge of self-protection measures, besides the awareness and participation of the various community stakeholders in determining strategies to reduce disaster risks with planning and increased awareness.

Finally, it shows the importance of care in its various concretizations, understandable by all and capable of inspiring fundamental values and attitudes that strengthen the culture of resilience, simultaneously contributing to the self-protection of communities in situations of disaster risk, considering the community of the world in authentic co-humanity, regardless of whether a situation experienced is easy to cope with or challenging, accompanied by risk of major disaster.

\section{References}

[1] Baptista, A. C., and Calijuri, M. L. 2007. "Caracterização Espaço-Temporal por Sessoriamento Remoto da Expansão Urbana na APA Petrópolis.” Presented at Anais XIII Simpósio Brasileiro de Sensoriamento Remoto, INPE-Florianópolis, Brasil. (in Portuguese)

[2] Nunes, J. P. S. 2012. "Crescimento Urbano e Experiência Suburbana em Lisboa-O caso da Amadora (1960-1974)." Crítica e Sociedade: Revista de Cultura Política 2 (2): 1-21. (in Portuguese)

[3] Spiegelberg, H. 1971. The Phenomenological Movement: A Historical Introduction. Vol. 1. The Hague, Netherlands: Martinus Nijhoff, 522p.

[4] Merleau-Ponty, M. 1996. Fenomenologia da Percepção. edited by Carlos, A. R. M. São Paulo: Martins Fontes. (in Portuguese)

[5] Fraga, V. F. 2009. Gestão pela Formação Humana: Uma Abordagem Fenomenológica. 2nd ed. São Paulo: Manole. (in Portuguese)

[6] Lima, D. M. C., Fraga, V. F., and Oliveira, F. B. 2016. "O Paradoxo da Reforma do Judiciário: Embates Entre a nova Gestão Pública e a Cultura Organizacional do Jeitinho." Rev. Adm. Pública 50 (6): 893-912. Accessed May 29, 2017. http://dx.doi.org/10.1590/0034-7612152 761. (in Portuguese)

[7] Dartigues, A. 1973. O que é a Fenomenologia?., edited by Maria, J. J. G. A. 2nd ed. Rio de Janeiro: Eldorado. (in 
Portuguese)

[8] Souza, L. A. A. 1995. Considerações Sobre o Plano Koeler. 150 anos da Colonização Alemã em Petrópolis. Petrópolis, Rio de Janeiro: Instituto Histórico de Petrópolis (IHP). (in Portuguese)

[9] Serpa, A. M. M. 2017. "Solução para Enchentes Passa por Políticas Públicas.” Diário de Petrópolis, Petrópolis, Rio de Janeiro. Accessed February 5, 2017. http://diariodepetropolis.com.br/integra/solucao-para-enc hentes-passa-por-politicas-publicas-109948.

(in Portuguese)

[10] Castro, J. V. R. 2016. "Carta Municipal do Espaço Público da Amadora." Dissertação de mestrado, Faculdade de Ciências Sociais e Humanas, Universidade Nova de Lisboa, Lisboa. Accessed March 16, 2017. http://www.rcaap.pt/detail.jsp?id=oai:run.unl.pt:10362/19 655. (in Portuguese)

[11] Salgueiro, T. B. 1987. "Os Transportes no Desenvolvimento das Cidades Portuguesas. Dossiê: A Cidade em Portugal: Onde se vive." Povos e Culturas, Lisboa 2: 113-44. (in Portuguese)

[12] Champion, T. 2001. Urbanization, Suburbanization, Counterurbanization and Reurbanization. Handbook of Urban Studies, edited by Paddison, R. London: Sage, 143-61.

[13] Mendes, L. 2008. "Urbanização Clandestina e Fragmentação Socio-Espacial Urbana Contemporânea: O Bairro da cova da Moura na Periferia de Lisboa." Revista da Faculdade de Letras da Universidade do Porto-Geografia 2 (2): 57-82. (in Portuguese)

[14] Sic Notícias. 2011. "Temporal Provocou Estragos em todo o País." Sic Notícias, Portugal. Accessed March 16, 2017. http://sicnoticias.sapo.pt/pais/2011-05-28-temporal -provocou-estragos-em-todo-o-pais. (in Portuguese)

[15] Wittgenstein, L. 1988. Investigaciones Filosóficas. Barcelona: UNAN-Crítica-Grijalbo. (in Portuguese)

[16] Margulis, M. 2009. Sociología de la Cultura: Conceptos $y$ Problemas. Buenos Aires: Biblos. (in Portuguese)

[17] Barthes, R. 1990. La Aventura Semiológica. Barcelona: Paidós. (in Portuguese)

[18] Jacobs, J. 2000. Morte e vida das Grandes Cidades. São Paulo: Martins Fontes. (in Portuguese)

[19] Souza, V. C. B., and Goldenfum, J. A. 2001. "Trincheiras de Infiltração como Elemento de Controle do Escoamento Superficial: Um Estudo Experimental." Avaliação $e$ controle da drenagem Urbana, edited by Tucci, C. E. M, and Marques, D. M. L. M. Porto Alegre: Universidade-UFRGS/ABRH. (in Portuguese)

[20] Prefeitura de Petrópolis. 2016. "Bomtempo faz Balanço da Resposta do Município às Chuvas do Rio de Janeiro." Accessed February 5, 2017. http://www.petropolis.rj.gov. br/pmp/index.php/imprensa/noticias-2/item/4331-bomtem po-faz-balan $\% \mathrm{C} 3 \% \mathrm{~A} 7 \mathrm{o}$-da-resposta-do-munic $\% \mathrm{C} 3 \% \mathrm{AD}$ pio-\%C3\%A0s-chuvas-de-janeiro.html. (in Portuguese)

[21] Jornal do Brasil. 2013. "O Minstério Público vai Entrar com Ação para Solucionar Problemas de Cheias em Petrópolis.” Rio. Jornal do Brasil. Accessed February 5, 2017. http://www.jb.com.br/rio/noticias/2013/03/20/mp-v ai-entrar-com-acao-para-solucionar-problemas-de-cheiasem-petropolis/.

[22] Amaral, D. P. B., Charge, L. T., and Júnior, J. E. F. 2015. “Aplicação de Ferramentas Computacionais na Gestão do risco à Inundações: Estudo de caso da Bacia Hidrográfica do Rio Quitandinha-Petrópolis/RJ.” Presented at XXI Simpósio Brasileiro de Recursos Hídricos. Segurança Hídrica e Desenvolvimento Sustentável: Desafios do Conhecimento e da Gestão. ABRH, Brasília. (in Portuguese)

[23] Público. 2014. "Autor do Plano de Drenagem de Lisboa Defende 'Intervenções Prioritárias' na Cidade.” Público, Portugal. Accessed March 16, 2017. https://www.publico.pt/2014/10/16/local/noticia/autor-do -plano-de-drenagem-de-lisboa-defende-intervencoes-prio ritarias-na-cidade-1673165. (in Portuguese)

[24] Camara Municipal de Amadora. 2016. "Projeto de Regulamentação de Drenagem de Águas Residuais dos Serviços Intermunicipalizados de água e Sanemaento dos Municípios de Oeiras e Amadora." Publicitação de início do Procedimento e Participação Procedimental. SIMAS Oeiras e Amadora. Accessed March 16, 2017. http://www.cmamadora.pt/images/artigos/extra/amadorai nforma/editais_avisos_comunicados/pdf/2016/proj_reg_d renagem_simas.pdf. (in Portuguese)

[25] Canholi, A. P. 2014. Drenagem Urbana e Controle de Enchentes. 2nd ed. São Paulo: Oficina de Textos. (in Portuguese)

[26] Gonzalez, F. C. G. 2014. "Projeto de Drenagem Sustentável para Mitigação de Cheias na Bacia do Rio Quitandinha, em Petrópolis, RJ.” Projeto de Graduação, Curso de Engenharia Ambiental da Escola Politécnica da Universidade Federal do Rio de Janeiro/Rio de Janeiro. Accessed February 5, 2017. http://www.drhima.poli.ufrj. br/images/documentos/tcc/2014/fernnanda-cristina-gonca lves-2014.pdf (in Portuguese)

[27] Pompêo, C. A. 2000. "Drenagem Urbana Sustentável." Revista Brasileira de Recursos Hídricos 5 (1): 15-23. (in Portuguese)

[28] Lefebvre, H. 2001. O Direito à Cidade. São Paulo: Centauro. (in Portuguese)

[29] Prefeitura de Petrópolis. 2017. "Núcleos Comunitários da Defesa Civil (Nudecs). Secretaria de Proteção e Defesa Civil do Município de Petrópolis.” Petrópolis, Rio de Janeiro. Accessed February 5, 2017. http://www.petro polis.rj.gov.br/dfc/index.php/cursos/nudecs.html. (in 


\section{Recurrent Unfavourable Climatic Phenomena}

Portuguese)

[30] Diário de Petrópolis. 2017. "Projeto Calçada Limpa é Aprovado em Primeira Discussão na Câmara.” Diário de Petrópolis, Petrópolis, Rio de Janeiro. Accessed May 30, 2017. http://diariodepetropolis.com.br/integra/projetocalcada-limpa-e-aprovado-em-primeira-discussao-na-cam ara-121962. (in Portuguese)

[31] Globo. 2016. "Comerciantes Investem na Proteção Contra Enchentes.” Região Serrana. G1. Globo, Brasil. Accessed February 5, 2017. http://g1.globo.com/rj/regiaoserrana/rjintertv-1 edicao/videos/v/comerciantes-investem -na-protecao-contra-enchentes-em-petropolis-rj/2362606/. (in Portuguese)

[32] Carvalho, L., Carrasco, U., Farinha, M., Batista, S., Fernandes, J. M., Sousa, G., and Leitão, N. 2013. "Risco, Desastre e Resiliência-Um Desafio para a Cidade da Amadora." Presented at IX Congresso da Geografia Portuguesa: Geografia, Espaço e Natureza. Universidade de Évora, Portugal. (in Portuguese)

[33] Dewey, J. (1979). The Quest for Certainty. New York: Paragon Books.

[34] Santos, F. T. 2009. Territórios Resilientes Enquanto Orientação de Planeamento. Lisboa: Direção de Prospectiva e Planeamento. (in Portuguese) 